\title{
Annual reproductive pattern in the springhaas, Pedetes capensis
}

\author{
M. van der Merwe, J. D. Skinner and R. P. Millar* \\ Mammal Research Institute, University of Pretoria, and \\ *Department of Chemical Pathology, University of Cape Town, South Africa
}

\begin{abstract}
Summary. The springhaas, Pedetes capensis, is capable of breeding throughout the year in the Orange Free State province of South Africa and fetuses of all sizes were found throughout the year. The highest incidence of pregnancies was found during the winter months July and August with the majority of embryos and small fetuses occurring between April and July and most larger fetuses thereafter. Birth weight was probably 280-300 g. Juveniles stay in the burrows until they have attained a body mass of $1.5 \mathrm{~kg}$. Once spermatogenesis is established at a liveweight of about $2.5 \mathrm{~kg}$ it appears to be continuous. There was an indication that plasma $\mathrm{LH}$ and progesterone concentrations were related to corpus luteum diameter.
\end{abstract}

\section{Introduction}

The springhaas (genus Pedetes) is a large bipedal rodent occurring throughout southern Africa (Misonne, 1974) where it is of some economic value as a source of protein, particularly in remote areas and for nomadic tribes (Smithers, 1971; Butynski, 1973). Little is known about its reproduction. Smith (1965) published preliminary data on ageing criteria and Coe (1969) described the anatomy of the reproductive tract, while Glover (1973) negated previous suggestions that Pedetes could be considered as a testicond mammal. Both Smithers (1971) and Butynski (1978) present data on pregnancy rates in Botswana. The object of the present study was to examine seasonal patterns in reproduction in an area subject to seasonal climatic variations.

\section{Study area and Methods}

\section{Animals}

The 223 animals (107 males, 116 females) were all shot at night during a culling programme in the Willem Pretorius Game Reserve $\left(28^{\circ} 18^{\prime} \mathrm{S}, 27^{\circ} 15^{\prime} \mathrm{E}\right)$ in the central Orange Free State, from March 1975 to March 1976. Various features of the Willem Pretorius Game Reserve, including climatological data for the period 1962-1971, are given by Bourquin (1973). It is situated in the summer rainfall area with an annual mean precipitation of $520.8 \mathrm{~mm}, 75 \%$ of the rainfall falling between October and April. The mean minimum daily temperature for the coldest month (June) is $0.9^{\circ} \mathrm{C}$ while the mean maximum daily temperature for the hottest month (January) is $34.2^{\circ} \mathrm{C}$. Temperatures and rainfall illustrated in Text-fig. 2 are those for Virginia $\left(28^{\circ} 06^{\prime} \mathrm{S}, 26^{\circ} 53^{\prime} \mathrm{E}\right)$, the nearest weather station $(41 \mathrm{~km})$ to the Game Reserve, in 1975 and 1976.

Immediately after death, blood was withdrawn from the heart with individual plastic disposable syringes, transferred to heparinized glass tubes and separated by centrifugation. The plasma was frozen within $60 \mathrm{~min}$ of death and stored at $-20^{\circ} \mathrm{C}$ for $1-6$ months. The reproductive tract was then dissected, examined and preserved in a mixture of ethyl alcohol 
( $95 \%$ ), formalin $(40 \%)$, glacial acetic acid and distilled water ( $3: 1: 1: 5$ by vol.). Fetuses were weighed and gonads were removed and weighed. After routine paraffin-wax embedding, pieces of the gonads were sectioned at $7 \mu \mathrm{m}$ and stained with Delafield's haematoxylin and eosin. Morphology of the ovaries was related to reproductive state and site of fetal implantations. The ovaries were sliced open in order to determine the location and size of the single corpus luteum.

To assess body condition the right buttock of each individual was dissected into bone, muscle and fat according to the method of Von La Chevallerie \& Van Zyl (1971).

\section{Hormone assays}

$L H$. Plasma LH was estimated as described by Millar \& Aehnelt (1977) using an antiserum to ovine LH (GDN No. 15) which has been demonstrated specifically to measure LH in a variety of mammalian species. Sensitivity of the assay was $39 \mathrm{pg} / \mathrm{ml}$, and the coefficient of variation within a single assay was $2 \cdot 1 \%$ and the coefficient of variation of a single sample tested in 5 assays was $18 \%$.

Testosterone. The estimations were performed on ether extracts of plasma using an antiserum to testosterone-3-carboxymethyl-oxime conjugated to bovine serum albumin as described by Millar \& Kewley (1976). This antiserum is highly specific for testosterone. Crossreaction with all major naturally occurring steroids was $<0 \cdot 1 \%$ except for dihydrotestosterone for which it was $5.1 \%$. The intra- and inter-assay coefficients of variation were 3.4 and $9.9 \%$ respectively.

Progesterone. Plasma progesterone values were determined in petroleum ether extracts using an antiserum raised against progesterone-11-hemisuccinate-bovine serum albumin (Lindner, Perel, Friedlander \& Zeitlin, 1972). Cross-reaction with all major naturally occurring steroids was $<2.6 \%$ except for $20 \alpha$-dihydroprogesterone for which it was $12.5 \%$. The intra- and interassay coefficients of variation were 2.5 and $14 \%$ respectively.

\section{Results}

The heaviest fetus, just before birth, weighed $290 \mathrm{~g}$, but no individual less than $1.5 \mathrm{~kg}$ was shot, indicating that juveniles only leave their burrows at a relatively advanced stage. Testicular histology showed that the males become sexually mature from a liveweight of about $2.5 \mathrm{~kg}$, and animals of $\geqslant 2.5 \mathrm{~kg}$ were shot throughout the year.

\section{The male}

In some of the mature males examined the testes were scrotal, although in the majority they were situated in the inguinal canals.

The relationship between mean combined testes weight and bodyweight is plotted in Text-fig. 1 and shows an exponential curve indicated by the equation $y=0.01 \mathrm{e}^{2 \cdot 53 x}$ (where $y=$ mean combined testes weight and $x=$ body weight). The coefficient of determination $\left(r^{2}\right)$ was calculated at 0.72 , indicating a highly significant $(P<0.001 ; n=99)$ exponential relationship between these two variables, until a body weight $(x)$ of $3.2 \mathrm{~kg}$ is obtained. In 5 sexually immature males which weighed $1.96-2.5 \mathrm{~kg}$ mean $\mathrm{LH}$ value was $0.84 \pm 0.71 \mathrm{ng} / \mathrm{ml}$ and the mean testosterone concentration was $1.2 \pm 0.69 \mathrm{ng} / \mathrm{ml}$. In seminiferous tubules of all males above a weight of $2.5 \mathrm{~kg}$ the full spermatogenic cycle was observed, indicating the ability to fertilize eggs throughout the year. Mean combined testes weight $(\mathrm{g})$ was linearly related to mean seminiferous tubule diameter $(\mu \mathrm{m})$ by the equation $y=2.65 x+143.6$ (where $y=$ mean seminiferous tubule diameter and $x=$ mean combined testes weight). The correlation coefficient $(r)$ of 0.61 is highly significant $(P<0.001 ; n=88)$. 


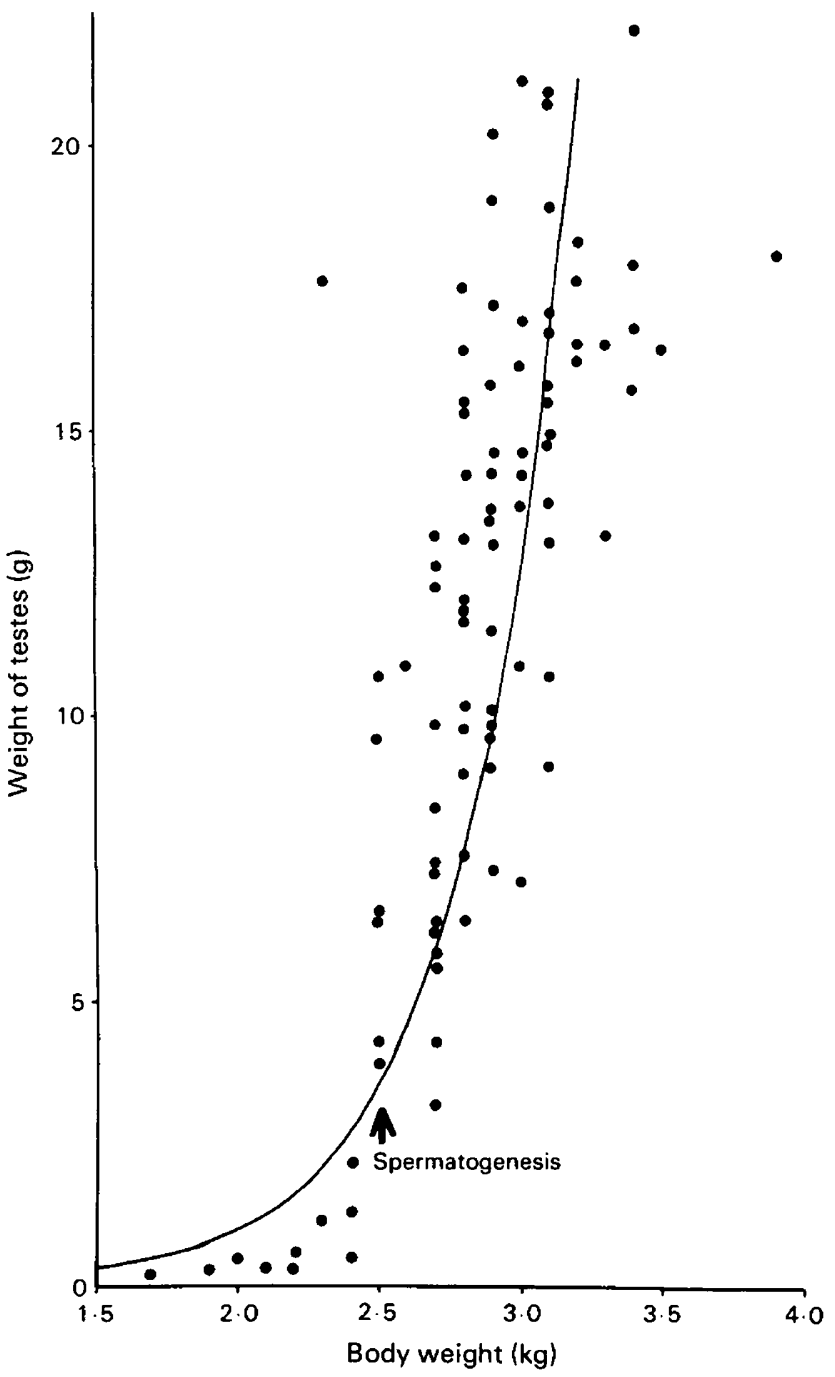

Text-fig. 1. Mean combined testes weight plotted against body weight of springhaas.

The relationship of mean testicular and epididymal weights to mean monthly climatic variables is shown in Text-fig. 2. The correlation coefficients $(r)$ between the combined testes weight $(\mathrm{g})$ and the photoperiod, rainfall and temperature were $-0.61,-0.66$ and -0.63 respectively. Although none of these relationships is significant, a definite trend could be seen of a peak in reproductive values at times of troughs in climatic variables and vice versa. Although males with spermatogenically active testes were found throughout the year, there was a suggestion of a peak of activity in July/August, a time when maximum mean plasma testosterone and $\mathrm{LH}$ concentrations (Table 1) and the highest percentages of pregnant females (Table 2) were also recorded. A decrease in all these features was again discernible during the warmer months from January to March.

Baculum weight increased significantly with age. When plotted against body weight, it followed an exponential curve indicated by the equation $y=0.003 \mathrm{e}^{1.35 x}$ (where $y=$ baculum weight and $x=$ body weight). The coefficient of determination $\left(r^{2}\right)$ was 0.50 and highly significant $(P<0.001 ; n=87)$. 
Table 1. Mean \pm 1 s.d. plasma concentrations of $\mathrm{LH}$ and testosterone in male springhaas

\begin{tabular}{lccc}
\hline \multicolumn{1}{c}{ Month } & $\begin{array}{c}\text { No. of } \\
\text { animals }\end{array}$ & $\begin{array}{c}\text { LH } \\
(\mathrm{ng} / \mathrm{ml})\end{array}$ & $\begin{array}{c}\text { Testosterone } \\
(\mathrm{ng} / \mathrm{ml})\end{array}$ \\
\hline June 1975 & 3 & - & $1.70 \pm 0.42$ \\
July 1975 & 5 & $1.78 \pm 0.60$ & $2.28 \pm 1.43$ \\
August 1975 & 5 & $2.17 \pm 2.09$ & $1.73 \pm 0.74$ \\
September 1975 & 5 & $1.07 \pm 0.45$ & $2.14 \pm 1.02$ \\
October 1975 & 7 & $1.29 \pm 0.55$ & $1.27 \pm 0.63$ \\
November 1975 & 6 & $2.10 \pm 1.66$ & $1.80 \pm 0.97$ \\
January 1976 & 3 & $0.95 \pm 1.09$ & $1.65 \pm 0.93$ \\
February 1976 & 3 & $0.57 \pm 0.64$ & $0.23 \pm 0.23$ \\
\hline
\end{tabular}

Table 2. Reproductive status of springhaas females sampled each month

\begin{tabular}{|c|c|c|c|c|c|}
\hline \multirow[b]{2}{*}{ Month } & \multirow{2}{*}{$\begin{array}{l}\text { No. of } \\
\text { nulliparous } \\
\text { females }\end{array}$} & \multicolumn{4}{|c|}{ Parous females } \\
\hline & & Total & No. not pregnant & No. pregnant & No. lactating \\
\hline March 1975 & 2 & 5 & 1 & 3 & 1 \\
\hline April 1975 & 6 & 8 & 5 & 3 & - \\
\hline May 1975 & 3 & 6 & 1 & 5 & - \\
\hline June 1975 & 3 & 7 & 1 & 5 & 1 \\
\hline July 1975 & 1 & 7 & - & 7 & - \\
\hline August 1975 & 2 & 9 & - & 8 & 1 \\
\hline September 1975 & 4 & 11 & - & 7 & 4 \\
\hline October 1975 & 4 & 8 & - & 4 & 4 \\
\hline November 1975 & 3 & 5 & 3 & 2 & - \\
\hline January 1976 & 7 & 1 & 1 & 一 & - \\
\hline February 1976 & 2 & 3 & 2 & 1 & - \\
\hline March 1976 & 2 & 7 & 7 & - & - \\
\hline
\end{tabular}

\section{The female}

In all pregnant females the single embryo had implanted on the same side as the corpus luteum, i.e. the side of ovulation. Of 45 pregnant females $59 \%$ had ovulated and implanted in the left uterine horn and $41 \%$ in the right uterine horn. The reproductive status of females sampled each month is illustrated in Table 2. There was a negative significant correlation between percentage pregnant females and photoperiod and rainfall $(r=-0.79$ and -0.74 respectively; $P<0.01 ; n=10)$. The relationship between percentage pregnant females and mean monthly temperature was highly significant $(r=0.84 ; P<0.001 ; n=10)$.

It is apparent from Table 2 that pregnant females were taken almost throughout the year except in December 1975 when no specimens were collected, and in January and March 1976. The highest incidence of pregnancy in mature females was during the colder months (March to August), and was followed by an increase in the percentage of lactating females.

The distribution of fetuses of different weights is illustrated in Table 3. Since small and large fetuses were present throughout the year, it can be concluded that there is no synchronized period of mating or parturition. However, most embryos were collected before July and most fetuses thereafter.

Progesterone levels $(\mathrm{ng} / \mathrm{ml})$ in pregnant females bearing embryos or fetuses within the same range of embryonic development or body weights (g) are given in Table 4. Although there was no significant correlation $(r=0.37 ; n=28)$ between fetal body weight and corpus luteum diameter there was an indication that the diameter of the corpus luteum decreased as fetal body weight increased since $y=5 \cdot 15-0 \cdot 12(\log \mathrm{e}) x$, where $y=$ corpus luteum diameter and $x=$ fetal 

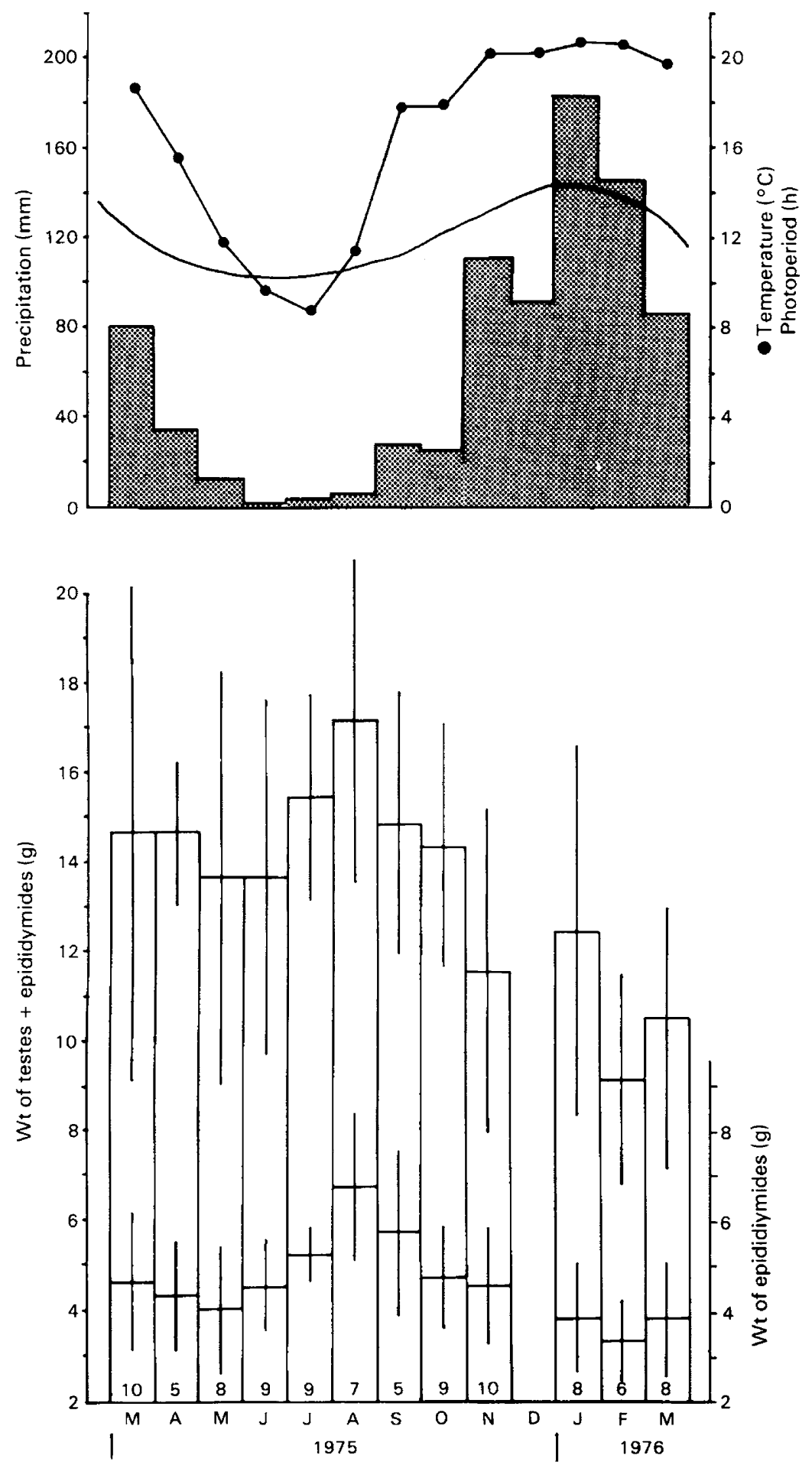

Text-fig. 2. Climatic variables and the combined weights (mean \pm 1 s.d.) of testes and epididymides and of epididymides from springhaas. The numbers in the monthly samples are indicated. 
Table 3. Weights of embryos and fetuses in springhaas collected during different months

\begin{tabular}{lcl}
\hline & \multicolumn{2}{c}{ Fetuses } \\
\cline { 2 - 3 } \multicolumn{1}{c}{ Month } & No. & \multicolumn{1}{c}{ Weight (g) } \\
\hline March 1975 & 3 & $<0 \cdot 3,0 \cdot 3,33 \cdot 9$ \\
April 1975 & 3 & $<0 \cdot 3,1 \cdot 6,290 \cdot 0$ \\
May 1975 & 5 & $<0 \cdot 3,<0 \cdot 3,<0 \cdot 3,<0 \cdot 3,0 \cdot 4$ \\
June 1975 & 5 & $<0 \cdot 3,<0 \cdot 3,<0 \cdot 3,<0 \cdot 3,5 \cdot 1$ \\
July 1975 & 7 & $<0 \cdot 3,<0 \cdot 3,0.4,1.9,2 \cdot 7,6 \cdot 1,6 \cdot 2$ \\
August 1975 & 8 & $<0 \cdot 3,8 \cdot 7,37 \cdot 4,40 \cdot 5,89 \cdot 2,105 \cdot 2,108 \cdot 5,127 \cdot 1$ \\
September 1975 & 7 & $<0 \cdot 3,0 \cdot 8,1 \cdot 4,24 \cdot 9,66 \cdot 7,182 \cdot 3,189 \cdot 3$ \\
October 1975 & 4 & $1 \cdot 1,134 \cdot 7,193 \cdot 2,241 \cdot 8$ \\
November 1975 & 2 & $<0 \cdot 3,29 \cdot 3$ \\
February 1976 & 1 & $17 \cdot 1$ \\
\hline
\end{tabular}

Table 4. Mean \pm 1 s.d. progesterone concentrations in female springhaas at different stages of pregnancy

\begin{tabular}{|c|c|c|c|}
\hline \multicolumn{2}{|c|}{ Weight of fetuses (g) } & \multirow{2}{*}{$\begin{array}{c}\text { No. of } \\
\text { samples }\end{array}$} & \multirow{2}{*}{$\begin{array}{l}\text { Progesterone } \\
\text { (ng/ml) }\end{array}$} \\
\hline Mean \pm s.d. & Range & & \\
\hline Primitive streak stage & - & 3 & $61.47 \pm 54.87$ \\
\hline $1.50 \pm 0.84$ & $0.8-2.7$ & 4 & $51 \cdot 18 \pm 24 \cdot 58$ \\
\hline $6.53 \pm 1.53$ & $5 \cdot 1-8 \cdot 7$ & 4 & $61.43 \pm 57.03$ \\
\hline $34.27 \pm 8.26$ & $24.9-40 \cdot 5$ & 3 & $92.57 \pm 20.29$ \\
\hline $77.95 \pm 15.91$ & $66.7-89.2$ & 2 & $77.95 \pm 15.91$ \\
\hline $123.43 \pm 13.48$ & $108 \cdot 5-134 \cdot 7$ & 3 & $60.75 \pm 16.20$ \\
\hline $24 \overline{1} \cdot 8$ & - & 1 & $33 \cdot 5$ \\
\hline
\end{tabular}

body weight $(\log \mathrm{e})$. Although not significant $(r=0.17 ; n=20)$ there was a positive relation between progesterone concentrations and corpus luteum diameter when expressed with the equation $y=3.91+0.19(\log \mathrm{e}) x$, where $y=$ corpus luteum diameter and $x=$ progesterone value. Concentrations of $\mathrm{LH}$ followed the same trend as those of progesterone but were also not significant $(r=0 \cdot 17 ; n=18)$ when expressed with the equation $y=4.49+0 \cdot 13(\log \mathrm{e}) x$, where $y$ $=$ corpus luteum diameter and $x=\mathrm{LH}(\log \mathrm{e})$ value, illustrating that LH concentrations were high in females during early pregnancy and declined as pregnancy progressed.

Body condition, as determined by percentage fat in the buttock, did not differ in the different months of the year. This is an indication that the carrying capacity of the Reserve for springhaas was not exceeded.

\section{Discussion}

Coe (1969) suspected that $P$. surdaster was a continuous breeder unlike $P$. capensis in South Africa which he classified as a seasonal breeder. In the Orange Free State, however, our investigations have proved $P$. capensis to be a continuous breeder. Moreover, we confirm the observations of Glover (1973) that Pedetes is not a testicond although Coe (1969) described springhaas testes as abdominal. However, Glover (1973) mentions the possibility that the testes of the springhaas can periodically be withdrawn into the abdomen, and we also found that the least pressure during examination causes the testes to move back into the inguinal canal. Glover (1973) considers that large inguinal canals and a coiled testicular artery are indicative of testicular descent during the evolution of a species.

An accurate gestation length for springhaas has not yet been recorded. Coe (1969) suggested 
that it was "up to 2 months" although Frazer \& Huggett (1974) wrongly credit him with giving it as 360 days. Rosenthal \& Meritt (1973) state that "The gestation period is not available but we feel that 80-82 days is possible" and Velte (1978) estimated it to be between 72 and 82 days. Our present data are insufficient to clarify the problem. Reported birth weights for $P$. surdaster (240-280 g: Coe, 1969) and P. capensis (250 g: Butynski, 1978; $300 \mathrm{~g}(\delta), 278 \mathrm{~g}$ (q): Rosenthal \& Meritt, 1973; $272 \mathrm{~g}(q)$ : Velte, 1978) indicate that the two largest fetuses in the present study were close to term.

We found that the springhaas is apparently able to reproduce throughout the year, although a peak in mating activity was apparent in July/August. The spread of pregnancies, and the good body condition throughout the year, can perhaps be attributed to their behaviour in feeding on underground rhizomes or surface stolons of 'quick' grasses (Smithers, 1971) which may ensure a more stable source of food throughout the year, and its burrowing habit. In the present study the pregnancy rate was $58 \%$ for 77 mature females. In Botswana, Smithers (1971) found $46 \%$ of a total of 227 females to be pregnant while Butynski (1978) recorded $76 \%$ pregnant females and $79 \%$ of those that were non-pregnant were lactating. In the present study only $34 \%$ of mature non-pregnant females were lactating, and $37 \%$ of all females collected were nulliparous. Since no females were pregnant and lactating, we conclude that the springhaas does not have a postpartum oestrus.

The present observations on reproduction in the springhaas do nothing to clarify the uncertain taxonomic position of the species and its family, the Pedetidae (Sclater, 1901; Ellerman, 1940; Simpson, 1945; Wood, 1955; McLaughlin, 1967). Fischer \& Mossman (1969) regarded the pedetids as rather specialized sciuromorphs on the basis of the fetal membranes and the remarkable resemblance of embryological details of Pedetes and Ctenodactylus (a gundi also of uncertain taxonomic affinities) suggests a close phylogenetic relationship.

We are grateful for the assistance of J. Langerman, J. Breytenbach and R. D. Carr during collection of specimens, and the Division of Nature Conservation of the Orange Free State, the M.R.C. and Professor M. C. Berman for co-operation and hospitality. Material for radioimmunoassay of $\mathrm{LH}$ was provided by Dr G. D. Niswender, Dr L. E. Reichert and NIAMDD. Support from the Harry Crossley Foundation is gratefully acknowledged.

\section{References}

Bourquin, O. (1973) Utilization and aspects of management of the Willem Pretorius Game Reserve. J. Sth Afr. Wildl. Mgmt Ass. 3, 65-73.

Butynski, T. M. (1973) Life history and economic value of the springhare (Pedetes capensis Forster) in Botswana. Botswana Notes and Records 5, 209213.

Butynski, T. M. (1978) Ecological studies on the springhare, Pedetes capensis in Botswana. Ph.D. thesis, Michigan State University.

Coe, M. J. (1969) The anatomy of the reproductive tract and breeding in the springhaas Pedetes surdaster larvalis Hollister. J. Reprod. Fert., Suppl. 6, 159174.

Ellerman, J. R. (1940) The Families and Genera of Living Rodents. British Museum (Natural History), London.

Fischer, T. V. \& Mossman, H. W. (1969) The fetal membranes of Pedetes capensis, and their taxonomic significance. Am. J. Anat. 124, 89-116.

Frazer, J. F. D. \& Huggett, A. St. G. (1974) Species variations in the foetal growth rates of eutherian mammals. J. Zool., Lond. 174, 481-509.
Glover, T. D. (1973) Aspects of sperm production in some East African mammals. J. Reprod. Fert. 35, $45-53$.

Lindner, H. R., Perel, E., Friedlander, A. \& Zeitlin, A. (1972) Specificity of antibodies to ovarian hormones in relation to the site of attachment of the steroid hapten to the peptide carrier. Steroids 19, 357-375.

McLaughlin, C. A. (1967) Aplodontoid, sciuroid, geomyoid, castoroid and anomaluroid rodents. In Recent Mammals of the World. A Synopsis of Families, pp. 210-225. Eds S. Anderson \& J. Knox Jones. Jr. The Ronald Press Company, New York.

Millar, R. P. \& Aehnelt, C. (1977) Application of ovine luteinizing hormone (LH). Radioimmunoassay in the quantitation of $\mathbf{L H}$ in different mammalian species. Endocrinology 101, 760-768.

Millar, R. P. \& Kewley, C. (1976) Production of a specific antiserum for testosterone. S. Afr. med.J. $\mathbf{5 0}$, 1021.

Misonne, X. (1974) Order Rodentia. In The Mammals of Africa: an Identification Manual, Part 6, pp. 1-39. Eds J. Meester \& H. W. Setzer. Smithsonian Institution Press, Washington, D.C. 
Rosenthal, M. A. \& Meritt, D. A. (1973) Hand-rearing springhaas at Lincoln Park Zoo. Int. Zoo Ybk 13, 135-137.

Sclater, W. L. (1901) The Mammals of South Africa, Vol. 11 . London.

Simpson, G. G. (1945) The principles of classification and a classification of mammals. Bull. Am. Mus. Nat. Hist. 85, 1-350.

Smith, C. C. (1965) Ageing criteria in the springhare, Pedetes capensis Forster. Arnoldia Rhod. 1, 1-6.

Smithers, R. H. N. (1971) The Mammals of Botswana.
Memoir No. 4, National Museums of Rhodesia, Salisbury.

Velte, F. F. (1978) Hand-rearing springhaas Pedetes capensis at Rochester Zoo. Int. Zoo Ybk 18, 206208.

Von La Chevallerie, M. \& Van Zyl, J. H. M. (1971) Growth and carcass development of the springbok Antidorcas marsupialis marsupialis. Agroanimalia 3, 115-124.

Wood, A. E. (1955) A revised classification of the rodents. J. Mammal. 36, 165-187.

Received 29 May 1979 